Ю. В. Супонько, Н. І. Штеменко

Дніпропетровський національний університет ім. Олеся Гончара

\title{
ВПЛИВ НАНОПРЕПАРАТІВ КЛАСТЕРНИХ СПОЛУК РЕНІЮ НА АКТИВНІСТЬ ФЕРМЕНТІВ ПЕЧІНКИ В МОДЕЛІ ПУХЛИННОГО РОСТУ
}

Вивчено рівень ферментативної активності гепатоцитів щурів за розвитку карциноми Герена, а також за введення сполук ренію і цисплатину. За одночасного введення цисплатину 3 кластерними сполуками ренію у наноліпосомній та водорозчинній формі спостерігалось зниження ферментативної активності до рівня контрольної групи тварин, що свідчить про гепатопротекторні властивості сполук ренію. Гепатопротекторні властивості кластерних сполук ренію здебільшого не залежать від форми їх уведення та виявляються незалежно від протипухлинних властивостей. Знайдено систему ренійплатину з $\beta$-аланіновим лігандом у водному розчині, введення якої супроводжусться гепатопротекторною дісю.

\author{
Ю. В. Супонько, Н. И. Штеменко
}

Днепропетровский национальный университет им. Олеся Гончара

\section{ВЛИЯНИЕ НАНОПРЕПАРАТОВ \\ КЛАСТЕРНЫХ СОЕДИНЕНИЙ РЕНИЯ НА АКТИВНОСТЬ ФЕРМЕНТОВ ПЕЧЕНИ В МОДЕЛИ ОПУХОЛЕВОГО РОСТА}

Изучен уровень ферментативной активности гепатоцитов крыс при развитии карциномы Герена, а также при введении соединений рения и цисплатина. При одновременном введении цисплатина с кластерными соединениями рения в нанолипосомной и водорастворимой форме наблюдалось снижение ферментативной активности до уровня контрольной группы животных, что свидетельствует о гепатопротекторных свойствах соединений рения. Гепатопротекторные свойства кластерных соединений рения в основном не зависят от формы их введения и проявляются независимо от противоопухолевых свойств. Найдена система рений-платина с $\beta$-аланиновым лигандом в водном растворе, введение которой сопровождается гепатопротекторным действием.

\author{
J. V. Suponko, N. I. Shtemenko \\ Oles’ Gonchar Dnipropetrovsk National University
}

\section{INFLUENCE OF NANO-CLUSTER COMPOUNDS OF RHENIUM DRUGS ON THE ACTIVITY OF LIVER ENZYMES IN A TUMOR MODEL}

Enzymes' level in rat's hepatocytes under Guerin's carcinoma T8 development as well as after injection of rhenium compounds and cis-platin has been studied. It has been determined that the decrease of enzymatic activity to the level of the animals of control group was observed at the simultaneous injection of cis-platin and cluster rhenium compounds in nanoliposomal and water-soluble forms. That confirms possible hepatoprotective properties of the rhenium compounds. It has been shown that hepatoprotective properties of rhenium cluster compounds mostly don't depend on the form of their injection and are detected regardless of anticancer properties. Rhenium-platinum system with $\beta$-alanine ligand in aqueous solution, has been found. Its injection is accompanied by the hepatoprotective effect.

(C) Ю. В. Супонько, Н. І. Штеменко, 2010 


\section{Вступ}

В умовах канцерогенезу відбувається інтоксикація організму, пошкодження гепатоцитів печінки при цьому веде до біохімічних і клінічних змін [3]. Більшість протипухлинних препаратів гепатотоксичні $[10 ; 12 ; 13 ; 15 ; 16]$. Цисплатин - ефективний протипухлинний препарат, що використовується в онкологічній практиці. Однак, поряд із високою ефективністю, цей препарат володіє цитотоксичною дією на нормальні тканини печінки $[11 ; 13 ; 14]$.

У наших попередніх роботах $[1 ; 3 ; 9]$ показано, що кластерні сполуки ренію проявляють антирадикальну, антигемолітичну активність у моделях in vitro та in vivo та $€$ біохімічними модуляторами цисплатину, тобто підсилюють його дію 3 одночасним зниженням токсичності. Подальший розвиток досліджень біологічної активності цих сполук і впровадження їх у медичну практику пов'язаний із вивченням механізмів їх взаємодії з клітинами печінки. Досліджено дію кластерних сполук ренію однакових структурних типів при різних формах уведення на показники ферментативної активності ферментів-маркерів цитолізу гепатоцитів у гомогенаті тканин печінки щурів із карциномою Герена на фоні введення цисплатину.

\section{Матеріал і методи досліджень}

У дослідженнях використовували такі форми комплексних сполук ренію (III): реній- $\beta$-аланін у водному розчині - ReßAla sln; реній- $\beta$-аланін у формі наноліпасом [ReßAla] nl. Дослідження проводили на білих безпорідних щурах масою тіла 100-150 г. Суспензія клітин карциноми Герена Т8 (30 \% у фізіологічному розчині) перещеплювалася здоровим щурам від пухлиноносіїв, отриманих в Інституті онкології та радіології ім. Р. О. Кавецького МОЗ України методом підшкірного уведення в ділянку стегна задньої кінцівки. Цисплатин уводили одноразово у дозі 8 мг/кг на 9-ту добу після трансплантації пухлини. Сполуки ренію вводили десятиразово, починаючи 3 третьої доби після перещеплення пухлини з інтервалом в 1 добу у кількості 7 мкмоль/кг ваги тварини кожне введення. Тварин поділено на групи: I - інтактні тварини; II - щури, яким трансплантували карциному Герена; III - щури-пухлиноносії, яким уводили цисплатин за схемою [17]; IV - щури-пухлиноносії, яким уводили T8+cPt+ReßAla sln; V щури-пухлиноносії, яким уводили T8+cPt+[ReßAla] nl.

Тварин декапітували на 21-шу добу після трансплантації пухлин. Гомогенат тканин печінки отримували шляхом ії гомогенізації у 10 мл фізіологічного розчину. Ферментативну активність АсАТ, АлАТ, ЛДГ визначали у надосадовій рідині, отриманій після центрифугування гомогенату. Для визначення активності ферментів застосовували загальноприйняті методи з використанням наборів реактивів (Філісіт-Діагностика, Україна). Статистичний аналіз даних проводили з використанням $t$-критерію Стьюдента, оцінюючи вірогідність отриманих результатів на рівні значимості не менше $95 \%$ $(p<0,05)$. Дані виражали у вигляді $M \pm m$.

\section{Результати та їх обговорення}

Основні патологічні процеси у печінці об'єднують у лабораторні синдроми 3 урахуванням індикаторних тестів: цитолізу, холестазу, гепатодепресії, запалення, шунтування печінки, регенерації. Усі вони супроводжуються гіперферментемією. Підвищення активності ферментів у гомогенаті тканин печінки за низкою патологій перш за все відбувається за рахунок виходу ензимів із тканин пошкодженого органа [4]. Перша причина розвитку гіперферментемії за патології - вихід ферментів у міжклітинне середовище 3 пошкоджених ділянок органа на фоні тривалого (посиленого) біосинтезу 
ензимів. Тривалість гіперферментемії зумовлена тим, що вихід ферментів із пошкоджених тканин і зниження їх вмісту у клітинах стимулюють за принципом зворотного зв'язку синтез останніх. Інша причина гіперферментемії - збільшення каталітичної активності ферментів як безпосередньо у пошкодженому органі, так і за потрапляння їх у міжклітинне середовище [3; 5].

Гепатоцити містять ряд маркерних ферментів: аспартатамінотрансфераза (АсAТ), аланінамінотрансфераза (АлАТ), лактатдегідрогеназа (ЛДГ), гаммаглутамінтрансфераза (ГГТ), лужна фосфатаза (ЛФ) [7; 8]. Одні з них містяться в цитозолі клітин (ЛДГ, АлАТ), інші - в мітохондріях (АсАТ) та в мембрані (ГГТ, ЛФ). Співвідношення величин АсАТ/АлАТ (коефіцієнт де Рітіса) вказує на природу пошкодження гепатоцитів і в нормі дорівнює одиниці. Синдром цитолізу виникає при пошкодженні клітин печінки та протікає на тлі вираженого порушення цілісності мембран гепатоцитів і їх органел, відмічається підвищення активності індикаторних ферментів: АСАТ, АЛАТ, ЛДГ і іiі ізоферментів ЛДГ4 і ЛДГ5. При синдромі холестазу, що супроводжується пошкодженням гепатоцитів, відбувається підвищення активності АлАТ, АсАТ та ЛФ. При некрозах гепатоцитів відбувається підвищення активності АлАТ, АсАТ, якщо некрози відсутні або низька активність процесу, активність АсАТ, АлАТ - у нормі. При хронічному активному гепатиті активність АсАТ підвищується, АлАТ - помірно збільшується, ЛДГ - підвищується. При жировій дистрофії печінки активність АсАТ і АлАТ - знижується, ЛДГ - норма. При цирозі печінки активність АсАТ помірно збільшується, АлАТ - збільшується, ЛДГ - норма. Активність ГГТ сироватки звичайно пов'язана з екскрецією ферменту, що синтезується в печінці, і в нормі незначна. Проте при захворюваннях печінки та жовчовивідних шляхів незмінно визначається підвищена активність ферменту в сироватці. Особливо висока активність ГГТ при дистрофії печінки, яка виникає в результаті онкозахворювань $[2 ; 6 ; 7 ; 18]$.

Розвиток карциноми Герена в експериментальних тварин (група II) супроводжується підвищенням активності всіх п'яти ферментів порівняно з контролем (група I). Це пов'язано 3 пошкодженням мембрани та некрозом клітини, супроводжується вивільненням у міжклітинний простір ферментів. При введенні цисплатину (група III) відмічено деяку стабілізацію функціонального стану печінки, хоча рівень токсичності залишається досить високим. Значне підвищення рівня амінотрансфераз - наслідок масивного пошкодження гепатоцитів, як це буває при важкій медикаментозній гепатотоксичності та ішемії (табл. 1).

Табличя 1

Активність амінотрансфераз у гомогенаті печінки щурів (мкмоль/год.॰мл), $(M \pm m, n=6)$

\begin{tabular}{|c|c|c|c|c|}
\hline Група & Назва сполуки & $\begin{array}{c}\text { Активність АсАТ, } \\
\text { мкмоль/год. } • \text { мЛ }\end{array}$ & $\begin{array}{c}\text { Активність АлАТ, } \\
\text { мкмоль/год. } \text { мл }\end{array}$ & $\begin{array}{l}\text { Коефіцієнт } \\
\text { де Рітіса }\end{array}$ \\
\hline I & Control & $3,20 \pm 0,01$ & $2,70 \pm 0,01$ & $1,19 \pm 0,01$ \\
\hline II & T8 & $4,84 \pm 0,02 *$ & $4,65 \pm 0,02 *$ & $1,04 \pm 0,02 *$ \\
\hline III & $\mathrm{T} 8+\mathrm{cPt}$ & $4,61 \pm 0,01 * *$ & $4,46 \pm 0,01 * *$ & $1,03 \pm 0,01 * *$ \\
\hline IV & $\mathrm{T} 8+\mathrm{cPt}+\mathrm{Re} \beta$ Ala $\sin$ & $3,80 \pm 0,05 * *$ & $3,33 \pm 0,02 * *$ & $1,14 \pm 0,06^{* *}$ \\
\hline $\mathrm{V}$ & $\mathrm{T} 8+\mathrm{cPt}+[\mathrm{Re} \beta \mathrm{Ala}] \mathrm{nl}$ & $3,93 \pm 0,01 * *$ & $3,61 \pm 0,02 * *$ & $1,09 \pm 0,02 * *$ \\
\hline
\end{tabular}

Примітки: * $-p<0,05$ відносно контролю; ** $-p<0,05$ відносно Т8.

При розвитку карциноми активність амінотрансфераз збільшується майже в 1,5 раза. Під дією цисплатину в умовах гальмування росту пухлини - на $13 \%$, активність АсАТ зменшується в середньому на $5 \%$, а АлАТ на $4 \%$. При введені комплексу $\mathrm{T} 8+\mathrm{cPt}+[\mathrm{Re} \beta \mathrm{Ala}] \mathrm{nl}$ спостерігається модулювальний і гепатопротекторний ефект, iз 
достовірним зниженням ферментативної активності на 19 та 22 \% порівняно з групою II. Редукція пухлини в даному випадку достовірна, становить 89 \%. При цьому коефіцієнт де Рітіса залишається в межах норми. Такий ефект пов'язаний скоріше за все зі стабілізацією певних структур мітохондріальної оболонки та зменшенням втрати складових речовин клітини під впливом реній-платинової системи.

При введенні T8+cPt+Re $\beta$ Ala sln активність амінотрансфераз знижується на 21 та $28 \%$ порівняно 3 Т8. При цьому не спостерігається значний вплив на перероджені клітини, що знижує проліферативну дію препарату. Його застосування веде до редукції пухлини достовірно лише на 48 \%. Обидві системи проявляють сильний гепатопротекторний ефект, зумовлений зниженням активності амінотрансфераз, що не залежить від форми введення та протипухлинних властивостей. Також відмічено зниження ферментативної активності ЛДГ та ГГТ при введенні чистого цисплатину в середньому лише на $5 \%$ (при редукції пухлини на $13 \%$ порівняно з Т8). Це свідчить про відсутність гепатопротекторних властивостей цисплатину як лікарського препарату.

При дослідженні кластерних сполук ренію з $\beta$-аланіновими лігандами при різних формах уведення як модуляторів фармакологічної дії цисплатину встановлено, що комплекси у розчині (група IV) та в наноліпосомній формі (група V) мають модулювальний ефект на ріст пухлини та виявляють незалежно від цього гепатопротекторну дію (група II). Це зумовлено зниженням активності ЛДГ на 10, 6 \% та ГГТ на 31, 17 \% відповідно (табл. 2).

Активність ЛДГ, ГГТ у гомогенаті печінки щурів (од./л), $(M \pm m, n=6)$

Табличя 2

\begin{tabular}{|c|l|c|c|}
\hline Група & \multicolumn{1}{|c|}{ Назва сполуки } & Активність ЛДГ, од./л & Активність ГГТ, од./л \\
\hline I & Control & $373,01 \pm 1,73$ & $22,30 \pm 0,35$ \\
\hline II & T8 & $416,00 \pm 2,30^{*}$ & $37,04 \pm 0,13^{*}$ \\
\hline III & T8+cPt & $395,50 \pm 1,50^{* *}$ & $35,34 \pm 0,25^{* *}$ \\
\hline IV & T8+cPt+Re $\beta A l a ~ s l n$ & $376,00 \pm 1,64^{* *}$ & $25,72 \pm 0,15^{* *}$ \\
\hline V & T8+cPt+[Re $\beta A l a] n l$ & $392,01 \pm 2,30^{* *}$ & $30,58 \pm 0,35^{* *}$ \\
\hline
\end{tabular}

Примітки: * $-p<0,05$ відносно контролю; ** $-p<0,05$ відносно Т8.

При канцерогенезі активність ЛФ (рис. 1) підвищується в 4,7 раза, що вказує на інтенсифікацію процесів дефосфорилювання, що підтримують внутрішньоклітинну концентрацію фосфату.

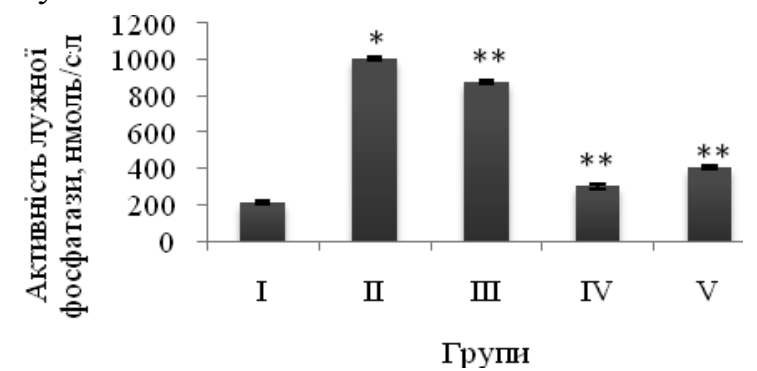

Рис. 1. Визначення активності ЛФ: * $-p<0,05$ відносно контролю; ** $-p<0,05$ відносно Т8; $n=6$; групи I-V - див. табл. 2.

Використання цисплатину як гепатопротектора призводить до зниження активності досліджуваного ферменту на 13 \% відповідно до групи Т8. У тварин із карциномою Герена, яким уводили цисплатин та ReßAla у вигляді розчину (група IV), відмічене інгібування активності ЛФ на 79 \%, а при введенні дослідним тваринам комплексу в наноліпосомній формі (група V) - на 60 \% порівняно з Т8. Отримані результати свідчать про незалежність 
гепатопротекторних властивостей реній-платинової системи з $\beta$-аланіновим лігандом від форми введення та модулювальних властивостей. Це вказує на їх різну біохімічну дію на такі процеси як проліферація та гепатопротекція.

\section{Висновки}

Уперше досліджено залежність гепатопротекторних властивостей кластерних сполук ренію від форми їх уведення. Гепатопротекторні властивості кластерних сполук ренію здебільшого не залежать від форми їх уведення та виявляються незалежно від протипухлинних властивостей. Знайдено систему реній-платина з $\beta$-аланіновим лігандом у водному розчині, введення якої супроводжується гепатопротекторною дією, що виявляється у значному зниженні (майже в 1,5 раза) активності досліджуваних ферментів.

\section{Бібліографічні посилання}

1. Антиоксидантні властивості кластерних комплексів ренію з деякими похідними масляної кислоти у плазмі крові та еритроцитах / Ю. П. Гриневич, С. А. Олійник, Н. І. Штеменко, О. В. Штеменко // Укр. біохім. журн. - 2003. - Т. 75, № 1. - С. 65-71.

2. Вивчення впливу комплексів ренію з органічними лігандами на кислотну резистентність еритроцитів людини / Н. І. Штеменко, І. В. Пірожкова-Паталах, А. В. Штеменко и др. // Укр. біохім. журн. - 2000. - Т. 72, № 3. - С. 77-81.

3. Івчук В. В. Функціональна активність гепатоцитів щурів при канцерогенезі / В. В. Івчук, Н. І. Штеменко // Вісник Дніпропетр. ун-ту. Біологія. Екологія. - 2008. - Вип. 16, т. 2. - С. 60-64.

4. Комаров Ф. І. Біохімічні дослідження в клініці / Ф. І. Комаров, Б. Ф. Коровкін, В. В. Меньшиков. - Эліста : Джангар, 1999. - 250 с.

5. Лабораторна ензимологія / Під ред. В. В. Долгова, А. В. Козлова, С. С. Ракова. - СПб. : Діагностікс СПб, 2002. - 160 с.

6. Подимова С. Д. Диференціальна діагностика жовтяниць // Клин. мед. - 2003. - № 12. - С. 66-71.

7. Соляник Г. І. Протипухлинна терапія. Допоміжна інформація / Г. І. Соляник, Г. І. Кулик. - К. : Геопринт, 1999. - 339 с.

8. Ткачук В. Е. Клінічна біохімія. - М. : Медицина, 2004. - 322 с.

9. Ходосова І. А. Ферменти клітин пухлин. - М. : Наука, 1998. - 235 с.

10. Яковенко Є. П. Хронічні захворювання печінки: діагностика та лікування // Рос. мед. журн. 2003. - T. 1, № 5. - C. 291-296.

11. A novel combination of cysplatin, irinotecan and capecitabine in patients with advanced cancer / M. Jefford, M. Michael, M. A. Rosenthal et al. // Invest. New Drags. - 2001. - Vol. 22, N 2. - P. 185-192.

12. Cersosimo R. J. Hepatotoxicity associated with cysplatin chemotherapy // Ann. Pharmacother. 1993. - Vol. 27, N 4. - P. 438-441.

13. Hematological side-effect profiles of individualized chemotherapy / M. Breidenbach, D. T. Rein, T. Schondorf et al. // Anticancer Drags. - 2003. - Vol. 14, N 5. - P. 341-346.

14. Kintzel P. E. Anticancer drag-induced kidney disorders // Drag Saf. - 2001. - Vol. 24. - P. 19-38.

15. Nephrotoxicity of platinum complexes is related to basolateral organic cation transport / T. Ludwig, C. Riethmuller, M. Gekle et al. // Kidney Int. - 2004. - Vol. 66, N 1. - P. 196-202.

16. Phase 2 trial of prolonged administration of oral topotecan in platinum/taxanerefractory ovarian, fallopian tube, and primary peritoneal cancers / M. Markman, K. Webster, K. Zanotti et al. // Gynecol. Oncol. - 2004. - Vol. 95, N 1. - P. 109-113.

17. Schimmel K. J. Cardiotoxicity of cytotoxic drugs / K. J. Schimmel, D. J. Richel, H. J. Guchelaar // Cancer Treat. Rev. - 2004. - Vol. 30, N 2. - P. 181-191.

18. Shtemenko N. Dichlorotetra- $\mu$-isobutyratodirhenium (III): Enhancement of cisplatin action and RBC-stabilizing properties / N. Shtemenko, P. Collery, A. Shtemenko // Anticancer Research. 2007. - Vol. 27. - P. 2487-2492.

Надійшла до редколегії 10.06.2010 